\title{
Dzikir Bersama Lansia Sebagai Upaya Menurunkan Gejala Psikosematis Dan Bakti Sosial Di Desa Cikampek Timur
}

\author{
Eneng Siti Julaeha, Irma Megawati \\ Program Studi Pendidikan Agama Islam, STAI DR. KHEZ. Muttaqien Purwakarta \\ e-mail: nengsitijulaeha24@gmail.com
}

DOI: https://doi.org/10.52593/svs.01.2.04

Naskah diterima: 10 Juli 2021, direvisi: 27 Juli 2021, disetujui: 28 Juli 2021

\begin{tabular}{ll}
\hline Abstract & This study focused on the importance of dzikir to reduce psychosematic \\
\hline Keywords: & symptoms that occur in the elderly in RT 03/09, East Cikampek Village, \\
Psychosematic, Dzikir & Karawang Regency. This study uses a qualitative field research method (field \\
& research) with a descriptive approach. Qualitative methods are used as a goal \\
& to be able to answer the problems that occur in the elderly in RT 03/09 East \\
& Cikampek Village. One indicator that can be measured from dzikir activities \\
& with the elderly is that it can be seen from changes in the behavior of the elderly \\
& who have carried out joint dhikr activities, this can be seen in some of the \\
& elderly who are starting to consistently participate in spiritual activities held \\
& at the local assembly.
\end{tabular}

Abstrak

Kata kunci:

Dzikir Lansia,

Psikosematis, Dzikir

\begin{abstract}
Penelitian ini difokuskan kepada pentingnya dzikir untuk menurunkan gejala psikosematis yang terjadi pada lansia di RT 03/09 Desa Cikampek Timur Kabupaten Karawang. Penelitian ini menggunakan metode penelitian kualitatif lapangan (field research) dengan pendekatan deskriptif. Metode kualitatif digunakan sebagai tujuan untuk dapat menjawab permasalahan yang terjadi pada lansia di RT 03/09 Desa Cikampek Timur. Selipkan pertanyaan penelitian Salah satu indikator yang dapat di ukur dari kegiatan dzikir bersama lansia yaitu dapat dilihat dari perubahan tingkah laku para lansia yang telah melaksanakan kegiatan dzikir bersama, hal ini terlihat pada beberapa lansia yang mulai konsisten mengikuti kegiatan-kegiatan kerohanian yang diselenggarakan di majlis setempat.
\end{abstract}

\section{PENDAHULUAN}

Manusia adalah makhluk yang eksploratif dan memiliki potensial. Manusia juga adalah makhluk yang mempunyai prinsip hidup dan tanpa daya, karena manusia membutuhkan orang lain untuk membantu dirinya dalam memenuhi tugas perkembangannya.

Dalam psikologi agama, atau dengan kata lain disebut sebagai ilmu jiwa, di dalamnya meneliti tentang pengaruh agama terhadap tingkah laku seseorang karena cara seseorang tersebut berfikir, bersikap, ataupun bereaksi. Tentu saja hal ini tidak terlepas dari keyakinannya terhadap agama, maka dari itulah ilmu jiwa dan agama adalah satu kesatuan.

Menurut Zakiyah (Darajat, 2010, 31) menyebutkan bahwa "Dalam kehidupan sehari-hari, ada orang yang rerlihat kehidupannya tenang, suka menolong, suka berbagi walaupun kehidupannya sederhana. Ada pula oramg yang selalu gelisah, cemas, suka marah-marah, perasaan tertekan, dan kecewa (dalam hal ini disebut Psiko-somatik)" walaupun kehidupannya tercukupi. Dan banyak juga orang yang kehidupannya berubah ke arah negative atau positif dengan durasi waktu yang singkat. Untuk meneliti hal inilah, maka ilmu jiwa agama (psikologi agama) diperlukan. 
Kehidupan manusia berproses melalui pertumbuhan dan perkembangan. Bertumbuh dikaitkan dengan perubahan kuantitatif, yaitu adanya perubahan fisik, seperti perubahan tinggi dan berat badan, bayi menjadi balita, anak-anak, remaja, dewasa sampai lanjut uisa. Sedangkan perkembangan disebut sebagai perubahan kualitatif, seperti perubahan dari tidak tahu menjadi tahu, dari tidak bisa menjadi bisa dan dari kekanak-kanakan menjadi dewasa.

Salah satu cabang ilmu psikologi, dijelaskan tentang tugas-tugas perkembangan, yaitu tingkat keterampilan, prestasi, dan penyesuaian diri yang di anggap urgent/penting pada tahap-tahap usia tertentu dan jika ingin tugas perkembangannya sukses, maka harus selesai pada rentang usia-usia tersebut.

Ada beberapa siklus pertumbuhan dan perkembangan manusia. Dari pre-natal sampai usia lanjut. Usia lanjut atau lansia merupakan siklus terakhir dalam proses pertumbuhan dan perkembangan manusia.

Pada usia lanjut, seharusnya seseorang memetik hasil dari apa yang diperolehnya, dan menikmatinya bersama anak dan cucunya. Dan seharusnya para lansia merasa bahagia karena telah memberikan sesuatu untuk generasinya. Namun berbeda dengan ekspetasi, lansia-lansia di Desa Cikampek Timur Rt.03/09 Kecamatan Cikampek Kabupaten Karawang, sedikit yang hidupnya makmur, bahagia, semangat beribadah, sehat fisik dan psikisnya, dan terjadi konflik pada lansia.

Pada penelitian yang penulis lakukan di Desa Cikampek Timur Kec. Cikampek Kab. Karawang, maka penulis memberi judul "Dzikir bersama Lansia sebagai Upaya menurunkan kecemasan Dan Bakti Sosial di Desa Cikampek Timur". Topik permasalahan yang terjadi di Desa Cikampek Timur Rt.03/09 terjadi pada para lasia usia 65-80 tahun.

Terdapat dua gejala psikologis atau tingkah laku yang ditimbulkan beberapa lansia ketika dilakukan observasi atau pengamatan. Tipe yang pertama adalah tipe pasrah. Lansia-lansia yang masuk kedalam tipe ini adalah lansia-lansia yang menerima dengan ikhlas, jika dirinya sudah tidak lagi eksis dilingkungannya, fungsi-fungsi fisik yang sudah mulai menurun, kehilangan pekerjaan karena ketidakberdayaannya. Lansia tipe ini masih pergi ke majlis ta'lim untuk mencari ilmu, kemudian tingkat spiritualnya semakin tinggi. Tipe yang kedua adalah tipe bingung. Lansia-lansia yang masuk kedalam tipe ini adalah kebalikan dari lansia tipe pasrah. Beberapa lansia yang peneliti observasi, masih belum menerima kenyataan, bahwa ia sudah tidak lagi eksis dilingkungannya, kehilangan pekerjaan, sering merasa bingung, dilanda kecemasan, rasa kecewa, menutup diri dari lingkungan dan juga minder, bahkan ada lansia yang sering marah dan juga sering mengkritik kepada orang lain secara terang-terangan. Lansia tipe ini sudah tidak pernah menginjakkan kakinya di majlis-majlis ilmu.

Kondisi ini diperparah dengan adanya wabah covid-19, ekonomi semakin sulit, para lansia yang hidup sendiri sudah mulai jarang diperhatikan warga maupun pemerintah. "Jangankan untuk pergi ke masjid, mikirin besok makan atau engga saja sudah sulit" begitu tutur salah satu lansia yang sudah tinggal sendiri.

Tujuan Peneliti dalam menyikapi permasalahan lansia yanga ada di Desa Cikampek Timur khususnya rt.03/09 adalah agar lansia kembali eksis dilingkungannya, merasa dihargai, kembali ke majlis-majlis Ta'lim/ilmu dan mendapat bantuan sosial guna menyambung kehidupannya walaupun hal ini bersifat temporary atau sementara. 


\section{METODE}

Metode yang digunakan dalam penelitian ini adalah metode kualitatif lapangan (field research) dengan pendekatan deskriptif. Penelitian kualitatif ini dapat dipandang sebagai prosedur penelitian yang menghasilkan data deskriptif berupa kata-kata tertulis atau lisan dari orang-orang dan perilaku yang dapat diamati.

\section{HASIL DAN PEMBAHASAN}

\section{Pengertian Psikologi Agama}

Psikologi agama merupakan gabungan dari kata psikologi dan agama. Psikologi berasal dari kata psyche yang berarti jiwa dan logos yang berarti ilmu. Segala aspek tingkah laku manusia secara terbuka dan tertutup dia sebagai individu maupun hubungan dengan lingkungannya menjadi wilayah psikologi. Ilmu ini juga menyelidiki penghayatan dan perbuatan yang dilakukan oleh manusia ditinjau dari fungsinya sebagai subjek.aspek jiwa sesorang menjadi sasaran utama dalam melihat segala keterkaitan perbuatan danalam jiwa seseorang, dalam hal ini psikologi juga dapat diartikan sebagai ilmu jiwa.

Kata agama sendiri berasal dari berbagai versi, menurut bahasa sansekerta agama berasal dari gabungan kata "a" yang berarti tidak dan "gama" yang berarti kacau.Maka agama diartikan sebagai suatu peraturan yang menuntun hidup manusia, budi pekerti, maupun hal-hal yang bersifat ghaib.5Seperangkat aturan itu yang dimaksud dengan wahyu, yang disampaikan oleh Tuan kepada manusia melalui seorang Rasul. Dalam bahasa Arab agama disebut al-Din. Kata al-Din sendiri memiliki beberapa arti yakni; Alihsan (kebajikan), al-adat (kebiasaan), altadzallulwa al-khudu (tunduk dan patuh), altha'at (taat), al-ibadat (pengbdian), al-Islam al tauhid (penyerahan dan pengesaan Tuhan). Agama merupakan seperangkat rasa tunduk terhadap sesuatu yang Maha Besar, sebagai konsekuensi dari ketundukan itu maka menjalankan segala macam ajaran yang dianjurkan dan diatur oleh agama itu dinilai sebagai satu tatanan ibadah atau penghambaan kepada Tuhan.Sedangkan Agama sendiri menurut Harun Nasution memiliki empat usur sebagaimana berikut :

1. Kekuatan ghaib, kekuatan Tuhan diyakini berada di atas kekuatan manusia. Hal ini terjadi karena berangkat dari kesadaran manusia akan keterbatasannya sehingga membutuhkan pertolongan dari kekuatan yang paling besar. Dengan demikian manusia dalam memenuhi hajat hidupnya akan selalu menjaga harmonisasi hubungannya dengan Tuhan yang dipercayi dengan berbagai realisasi tindakan, melaksanakan perintah dan menjauhi larangan-Nya.

2. Keyakinan kepada yang ghaib untuk menentukan nasib baik dan buruk. Pola hubungan yang selalu dijaga oleh sesorang sebagai hamba kepada Tuhannya membentuk pengharapan dari manusia untuk mendapatan balasan yang baik berupa surga dan tidak mengharapkan balasan siksaan berupa neraka.

3. Respon emosional dari manusia, respon emosional ini dapat dilihat melalui penyembahan manusia kepada Tuhan yang didorong oleh perasaan takut, juga pemujaan yang dilkukan sebagai bentuk cinta kepada Tuhannya dengan berbagai bentuk cara hidup tertentu bagi para penganutnya.

4. Paham yang meyakini adanya Sesutu yang suci atau hal yang dikuduskan (sacred). Sesuatu yang suci dan kudus ini kadangkala berupa sesuatu kekuatan yang ghaib. Kekuatan ghaib yang dimaksud adalah kepercayaan tehadap kekuatan Tuhan yang 
dikemudian menurunkan wahyu kepada umatnya. Wahyu Tuhan pada akhirnya ikut disucikan dengan anggapan menjaga wahyu Tuhan berarti menghargai Firman-Nya. Tempat-tempat ibadah juga tergolong sesuatu yang disucikan. Maka segala hal yang berhubungan dengan proses manusia mendekat dengan Tuhannya hal itu adalah sebuah kesucian atau yang dikuduskan.

\section{Peran Agama Terhadap Kesehatan Mental}

Tidak dapat dipungkiri bahwa setiap manusia menginginkan kepuasan. Baik kepuasan jasmani maupun psikis. Ingin merasa kenyang, merasa aman dan terlidungi, ingin dihargai harkat serta martabatnya, dan juga ingin mendapatkan simpati. Dari keinginan demi kepuasan tersebut muncul sebuah kesadaran akan arti dirinya dan kesadaran akan penguasaan. Di sinilah kemudian fungsi agama sebagai jalan hidup untuk mewujudkan keserasian yang sungguh- sungguh antara fungsi jiwa dan terbentuknya penyesuaian diri antar sesama umat manusia maupun terhadap lingkungannya yang berdasarkan cahaya keimanan dan ketqwaan.

Agama berkedudukan dasar sebagai pembina kesehatan mental bagi orang-orang yang menganut agama dan mengaplikasikan konsep ajaran agamanya di tengah masyarakat. Secara psikologis keberadaan agama memang merupakan sebuah respon terhadap Tuhan sebagai penguasa alam semesta dan sebagai suatu Realitas Mutlak yang terpancar dalam dirinya. Dengan agama manusia menyadari dengan sungguh hakikat keberadaanya serta tujuan hidupnya yang hakiki.

Prof. Dr. Zakiah Daradjat memaparkan bahwa gangguan kejiwaan atau kesehatan mental seseorang merupakan kumpulan-kumpulan keadaan yang tidak normal, baik menyangkut persoalan fisik maupun persoalan mental pada diri sesorang.

\section{a. Pengertian Psikosomatik}

Istilah psikosomatik menunjukkan hubungan antara jiwa dan badan. Gangguan psikosomatik didefinisikan sebagai suatu gangguan atau penyakit fisik dimana proses psikologis memainkan peranan penting, sedikitnya pada beberapa pasien dengan sindroma ini. Kellner (Kartikadewi, 2015).

Keluhan-keluhan psikosomatis dapat berupa, jantung berdebar-debar, sakit maag, sakit kepala (pusing, migren), sesak nafas dan lesu.

Menurut Kaplan, faktor penyebab psikosomatis adalah depresi dan kecemasan. Gangguan psikosomatis dapat timbul bukan saja pada yang berkepribadian atau emosi labil, tetapi juga pada orang yang dapat dikatakan stabil, atupun pada orang dengan gangguan kepribadian dan pada orang dengan psikosa. Menurut Teori Kelemahan Organ (Theory Of Somatic Weakness), gangguan psikosomatis akan terjadi pada seorang yang mempunyai organ yang secara biologis sudah lemah atau peka. Kelemahan bisa terjadi karena faktor genetic, penyakit atau luka sebelumnya.

\section{b. Pengertian Dzikir}

Secara etimologi Dzikir berasal dari kata dzakara artinya mengingat, memperhatikan, mengenang, mengambil pelajaran, mengenal atau mengerti dan mengingat. Menurut Chodjim dzikir berasal dari kata dzakara yang berarti mengingat, mengisi atau menuangi, artinya, bagi orang yang berdzikir 3berarti mencoba mengisi dan menuangi pikiran dan hatinya dengan kata-kata suci. 
Menurut Bastaman dzikir (Idris, 2016) adalah perbuatan mengingat Allah dan keagungan-Nya, yang meliputi hampir semua bentuk ibadah dan perbuatan seperti tasbih, tahmid, shalat, membaca al-Qur'an, berdoa, melakukan perbuatan baik dan menghindarkan diri dari kejahatan. Said Ibnu Djubair serta para ulama lainnya menjelaskan bahwa yang dimaksud dengan dzikir itu adalah semua ketaatan yang diniatkan karena Allah SWT, hal ini berarti tidak terbatas masalah tasbih, tahlil, tahmid dan takbir, tapi semua aktifitas manusia yang diniatkan kepada Allah SWT.

Dzikir adalah usaha manusia untuk mendekatkan diri pada Allah dengan cara mengingat Allah dengan cara mengingat keagungan-Nya, hal ini berarti tidak terbatas masalah tasbih, tahlil, tahmid dan takbir, tapi semua aktifitas manusia yang diniatkan kepada Allah SWT.

\section{Bentuk-bentuk Dzikir}

Seorang sufi yang menulis Al-Hikam (Kata-Kata Hikmah) membagi dzikir atas tiga bagian: zikir jali (zikir jelas, nyata), zikir khafi (zikir samar-samar) dan zikir haqiqi (zikir sebenar-benarnya)

\section{Zikir Jali}

Zikir Jali adalah suatu perbuatan mengingat Allah SWT. Dalam bentuk ucapan lisan yang mengandung arti pujian, rasa syukur dan doa kepada Allah SWT. Yang lebih menampakkan suara yang jelas untuk menuntun gerak hati. Mula-mula zikir ini diucapkan secara lisan, mungkin tanpa dibarengi ingatan hati. Hal ini biasanya dilakukan orang awam (orang kebanyakan). Hal ini dimaksudkan untuk mendorong agar hatinya hadir menyertai ucapan lisan itu.

2. Zikir Khafi

Zikir Khafi Adalah zikir yang dilakukan secara khusyuk oleh ingatan hati, baik disertai zikir lisan ataupun tidak. Orang yang sudah mampu melakukan dzikir seperti ini merasa dalam hatinya senantiasa memiliki hubungan dengan Allah swt. ia selalu merasakan kehadiran Allah SWT. Kapan dan dimana saja. Dalam dunia sufi terdapat ungkapan bahwa seorang sufi, ketika melihat suatu benda apa saja, bukan melihat benda itu, tetapi melihat Allah SWT. Artinya, benda itu bukanlah Allah swt, tetapi pandangan hatinya jauh menembus melampaui pandangan matanya tersebut. ia tidak hanya melihat benda itu akan tetapi juga menyadari akan adanya Khalik yang menciptakan benda itu.

3. Zikir Haqiqi

Yaitu zikir yang dilakukan dengan seluruh jiwa raga, lahiriah dan batiniah, kapan dan dimana saja, dengan memperketat upaya memelihara seluruh jiwa raga dari larangan Allah SWT. Mengerjakan apa yang diperintahkan-Nya. Selain itu tiada yang diingat selain Allah swt. Untuk mencapai tingkatan zikir haqiqi ini perlu dijalani latihan mulai dari tingkat zikir jali dan zikir khafi. Adapun bacaanbacaan yang dianjurkan dalam dzikir lisan menurut Hawari adalah sebagai berikut:

- Membaca tasbih (subhanallah) yang mempunyai arti Maha Suci Allah.

- Membaca tahmid (alhamdulillah) yang bermakna segala puji bagi Allah.

- Membaca tahlil (la illaha illallah) yang bermakna tiada Tuhan selain Allah.

- Membaca takbir (Allahu akbar) yang berarti Allah Maha Besar. 


\section{Fungsi Dzikir}

Shaleh Bin Ghanim As-Sadlan menyebutkan beberapa faedah-faedah atau keutamaan dzikir adalah sebagai berikut:

1. Mengusir, mengalahkan dan menghancurkan setan

2. Menghilangkan rasa susah dan kegelisahan hati

3. Membuat hati menjadi senang, gembira dan tenang.

4. Dapat menghapus dan menghilangkan dosa-dosa.

Adapun penelitian terdahulu yang menjadi referensi dari penelitian ini adalah : penelitian yang dilakukan oleh Atik Setiawan Wahyuningsih (2021) dengan judul jurnal "Terapi Dzikir Terhadap Perubahan Tingkat Stres Pasien Diabetes Melitus" dengan penelitian sebelum diberikan terapi dzikir banyak yang mengalami tingkat stres tinggi sebanyak 37 responden. Setelah diberikan terapi dzikir banyak yang mengalami tingkat stress rendah sebanyak 34 responden. Penelitian berikutnya yang dilakukan oleh Tria Widiatuti (2019) dengan jurnal jurnal "Terapi Zikir sebagai Intervensi untuk Menurunkan Kecemasan pada Lansia" dengan Kelompok eksperimen menunjukkan perbedaan signifikan skor kecemasan setelah intervensi diberikan. Dengan demikian, terapi zikir sebagai intervensi secara efektif mampu menurunkan kecemasan pada lansia.

Data penelitian ini di ambil pada bulan November 2020. Dengan adanya permasalahan lansia di Desa Cikampek Timur, MPP melakukan perencanaan untuk menyelenggarakan kegiatan lansia mengaji dan berdzikir, yang bertujuan agar lansia kembali bereksistensi dilingkungannya, merasa dihargai, kembali ke majlis-majlis ilmu dan mendapat bantuan sosial guna menyambung kehidupannya walaupun hal ini bersifat temporary atau sementara.

\section{Pra-tindakan}

Pada proses pra-tindakan, MPP berkolaborasi dengan beberapa pihak yaitu: Sekretaris desa, tokoh agama, tokoh masyarakat sekaligus pemilik majlis ta'lim at-taubah, ketua majlis ta'lim, ketua rt.03/09 dan juga subyek lansia itu sendiri.

Subjek penelitian adalah ibu-ibu usia lanjut/lansia di rt.03/09 Desa Cikampek Timur Kecamatan Cikampek Kabupaten Karawang. Jumlah lansia yang ada di RT 03/09 Desa Cikampek Timur yaitu 12 orang.

Setelah MPP melakukan kunjungan dengan berbagai informan, di dapatlah sebuah permasalahan yang mendorong MPP untuk melakukan suatu kegiatan. Permasalahan yang MPP temukan berasal dari kalangan lansia di Desa Cikampek timur, kemudian saya batasi dengan focus kepada lansia-lansia di rt.03/09 desa cikampek timur.

Adapun permasalahan lansia yang terjadi adalah :

1. Terjadi perubahan tingkah laku/psikologis pada lansia-lansia di desa cikampek timur rt.03/09

2. Beberapa lansia mengalami kecemasan, stress karna kehilangan istri/suaminya, kehilangan pekerjaan, sering marah dan bahkan mengkritik orang lain dengan terang-terangan.

3. Beberapa lansia mengasingkan diri di rumah, tidak pernah keluar rumah, merasa minder, merasa tidak berguna dan merasa sudah tidak dihargai lagi dilingkungannya. 
4. Beberapa lansia sudah tidak lagi menginjakkan kakinya di majlis-majlis ilmu, walaupun $80 \%$ kondisi fisinya masih mampu untuk mengunjungi majlis ta'lim.

5. Keadaan ekonomi yang semakin sulit karena adanya wabah covid-19, apalagi untuk beberapa lansia yang sudah tinggal sendiri. Biasanya lansia selalu mendapat bantuan sembako dari tetangganya, saat ini lansia sudah jarang mendapat bantuan konsumsi ataupun sembako.

Semenjak wabah covid-19, belum ada lagi bantuan dari pemerintah atau hal yang dilakukan oleh masyarakat kepada lansia-lansia yang ada di desa cikampek timur. Permasalahan-permasalahan lansia kurang mendapat perhatian, terlebih saat satu bulan kebelakang masyarakat desa di buat geger dengan adanya kasus yang terjadi pada kepala desa cikampek timur. Permasalahan-permasalahan lansia dinilai kurang mendapat perhatian.

\section{Pasca Tindakan}

Pada action yang dilakukan, MPP sebagai penyelenggara sekaligus menjadi pengatur acara kajian islam untuk lansia dan mengadakan kegiatan bakti sosial. Hal ini mengacu kepada permasalahan yang terjadi pada lansia di rt.03/09 desa cikampek timur yang sudah MPP paparkan sebelumnya.

Pada kajian islam yang MPP selenggarakan, MPP mengusung tema kajian "Lansia Mengaji: Keutamaan Dzikir sebagai upaya menurunkan kecemasan". Pada kegiatan ini, MPP tentu tidak sendiri, MPP mengundang beberapa pengisi acara seperti tokoh agama, pemilik majlis ta'lim, ketua majlis ta'lim, pembaca ayat suci al-quran dan yang menjadi subyek kajian islam yaitu para lansia.

MPP membatasi jumlah lansia yang di undang untuk kegiatan kajian, dikarenakan wabah covid-19. Dalam kondisi ini, MPP sekaligus membagikan masker, cara memakainya, menggunakan handsanitizer dan menjaga jarak.

\section{Produk/konsep baru}

Produk atau gagasan yang MPP lakukan adalah dengan menyelenggarakan kegiatan kajian islam dan bakti sosial khusus lansia dengan tema "Lansia Mengaji: Keutamaan Dzikir sebagai upaya untuk menurunkan kecemasan" di Desa cikampek timur kecamatan cikampek kabupaten karawang.

Tabel 1. Data lansia RT 03/09 Desa Cikampek Timur

\begin{tabular}{|c|l|l|l|l|}
\hline No & \multicolumn{1}{|c|}{$\begin{array}{c}\text { Nama di Kartu } \\
\text { keluarga }\end{array}$} & $\begin{array}{c}\text { Nama } \\
\text { Panggilan }\end{array}$ & \multicolumn{1}{|c|}{ Usia } & Keterangan \\
\hline 1. & Ibu Sarni & Mak Ani & 75 Tahun & \\
\hline 2. & Ibu Nipah & Ma Nipah & 70 Tahun & \\
\hline 3. & Ibu Endun & Mak Endun & 72 Tahun & \\
\hline 4. & Ibu Rumanah & Mak Minong & 75 Tahun & \\
\hline 5. & Ibu Anirah & Mak Enok & 80 Tahun & Sudah tidak berjalan \\
\hline 6. & Ibu Rumisah & Mak Nyai & 80 Tahun & \\
\hline 7. & Ibu Oneng & Mak Ucah & 75 Tahun & \\
\hline 8. & Bapak Obon & Ki obon & 80 Tahun & $\begin{array}{l}\text { Sudah tidak bisa } \\
\text { berjalan }\end{array}$ \\
\hline 9. & Bapak Maslim & Ki Maslim & 75 Tahun & \\
\hline
\end{tabular}


Tabel 2. Kegiatan Penelitian Berbasis Penelitian

\begin{tabular}{|c|c|c|c|c|}
\hline Tanggal & Nama kegiatan & $\begin{array}{l}\text { Tempat } \\
\text { kegiatan }\end{array}$ & Tema kegiatan & $\begin{array}{l}\text { Jumlah } \\
\text { Peserta }\end{array}$ \\
\hline $27 / 10 / 2020$ & $\begin{array}{l}\text { Menemui } \\
\text { Sekretaris Desa } \\
\text { Cikampek } \\
\text { Timur }\end{array}$ & $\begin{array}{l}\text { Kantor Kepala } \\
\text { Desa }\end{array}$ & $\begin{array}{l}\text { Sosialisasi PBP } \\
\text { dan Meminta } \\
\text { Perijinan } \\
\text { Kegiatan PBP } \\
\end{array}$ & 1 \\
\hline $28 / 10 / 2020$ & $\begin{array}{l}\text { Menemui Tokoh } \\
\text { Masyarakat } \\
\text { Desa Cikampek } \\
\text { Timur }\end{array}$ & $\begin{array}{l}\text { Rumah Bapak } \\
\text { Asep Saeful,S.Pd }\end{array}$ & $\begin{array}{l}\text { Sosialisasi PBP } \\
\text { dan meminta } \\
\text { perijinan majlis } \\
\text { ta'lim At-taubah }\end{array}$ & 1 \\
\hline $01 / 11 / 2020$ & $\begin{array}{lr}\text { Observasi } & \text { dan } \\
\text { silaturahmi } \\
\text { kepada } 8 \text { ibu } \\
\text { dan } 2 \text { bapak } \\
\text { lanjut usia }\end{array}$ & $\begin{array}{l}\text { Rumah masing- } \\
\text { masing }\end{array}$ & $\begin{array}{l}\text { Observasi dan } \\
\text { Wawancara }\end{array}$ & 1 \\
\hline $03 / 11 / 2020$ & $\begin{array}{l}\text { Menemui tokoh } \\
\text { agama desa } \\
\text { cikampek timur }\end{array}$ & $\begin{array}{l}\text { Rumah bapak H. } \\
\text { Empud } \\
\text { Syarifudin, S.Ag }\end{array}$ & $\begin{array}{l}\text { Sosialisasi PBP } \\
\text { dan undangan }\end{array}$ & 1 \\
\hline $5 / 11 / 2020$ & $\begin{array}{l}\text { Mengundang } \\
\text { para pengisi } \\
\text { acara }\end{array}$ & $\begin{array}{l}\text { Whatsapp dan } \\
\text { telepon }\end{array}$ & $\begin{array}{l}\text { Sosialisi PBP } \\
\text { dan undangan }\end{array}$ & 1 \\
\hline $7 / 11 / 2020$ & $\begin{array}{l}\text { Mengunjungi } \\
\text { tokoh } \\
\text { masyarakat }\end{array}$ & $\begin{array}{l}\text { Rumah bapak } \\
\text { Asep Saiful, S.Pd }\end{array}$ & $\begin{array}{l}\text { Menentukan } \\
\text { tanggal kegiatan } \\
\& \text { undangan } \\
\text { memberikan } \\
\text { sambutan }\end{array}$ & 1 \\
\hline $9 / 11 / 2020$ & $\begin{array}{l}\text { Mengunjungi } \\
\text { ketua rt 03/09 }\end{array}$ & $\begin{array}{l}\text { Rumah bapak } \\
\text { Nanang }\end{array}$ & $\begin{array}{l}\text { Menentukan } \\
\text { tanggal kegiatan } \\
\& \text { undangan } \\
\text { memberikan } \\
\text { sambutan } \\
\end{array}$ & 1 \\
\hline $11 / 11 / 2020$ & $\begin{array}{l}\text { Mengunjungi } \\
\text { rumah donatur }\end{array}$ & $\begin{array}{ll}\text { Rumah ibu } \\
\text { Linda } \\
\text { Mariskasari }\end{array}$ & $\begin{array}{l}\text { Sosialisasi PBP } \\
\text { dan } \\
\text { memberikan } \\
\text { data lansia }\end{array}$ & 1 \\
\hline $12 / 11 / 2020$ & $\begin{array}{l}\text { Mengunjungi } \\
\text { lansia }\end{array}$ & $\begin{array}{l}\text { Rumah masing- } \\
\text { masing lansia }\end{array}$ & $\begin{array}{l}\text { Mengundang } \\
\text { lansia \& } \\
\text { memberikan } \\
\text { kupon } \\
\text { pengambilan } \\
\text { sembako }\end{array}$ & 1 \\
\hline $15 / 11 / 2020$ & $\begin{array}{l}\text { Belanja bersama } \\
\text { donatur }\end{array}$ & $\begin{array}{l}\text { Super market } \\
\text { mall cikampek }\end{array}$ & $\begin{array}{l}\text { Belanja } \\
\text { kebutuhan } \\
\text { sembako untuk } \\
\text { lansia } \\
\end{array}$ & 1 \\
\hline $16 / 11 / 2020$ & $\begin{array}{l}\text { Packing } \\
\text { sembako }\end{array}$ & Rumah MPP & - & 1 \\
\hline
\end{tabular}


Dzikir Sebagai Upaya Menurunkan Gejala Psikosematis [Eneng Siti Julaeha]

\begin{tabular}{|l|l|l|l|l|}
\hline $16 / 11 / 2020$ & $\begin{array}{l}\text { Membuat } \\
\text { rundown acara }\end{array}$ & Rumah MPP & $\begin{array}{l}\text { "Lansia Mengaji } \\
: \text { Keutamaan } \\
\text { Dzikir untuk } \\
\text { menurunkan } \\
\text { gejala } \\
\text { psikosematis" }\end{array}$ & 1 \\
\hline $17 / 11 / 2020$ & $\begin{array}{l}\text { Pengajian } \\
\text { Lansia \& Bakti } \\
\text { Sosial }\end{array}$ & $\begin{array}{l}\text { Majlis Ta'lim At- } \\
\text { taubah }\end{array}$ & $\begin{array}{l}\text { "Lansia Mengaji } \\
: \text { Keutamaan } \\
\text { Dzikir untuk } \\
\text { menurunkan } \\
\text { gejala } \\
\text { psikosematis" }\end{array}$ & 10 \\
\hline $27 / 11 / 2020$ & $\begin{array}{l}\text { Mengunjungi } \\
\text { Kepala Desa }\end{array}$ & $\begin{array}{l}\text { Kantor kepala } \\
\text { desa }\end{array}$ & $\begin{array}{l}\text { Penyerahan } \\
\text { surat } \\
\text { keterangan \& } \\
\text { Penyerahan } \\
\text { Cendramata }\end{array}$ & 1 \\
\hline $30 / 11 / 2020$ & $\begin{array}{l}\text { Penyerahan } \\
\text { Laporan } \\
\text { Penelitian }\end{array}$ & Email & $\begin{array}{l}\text { Penyerahan } \\
\text { Laporan } \\
\text { Penelitian } \\
\text { Kepada Dosen } \\
\text { Pembimbing }\end{array}$ & 12 \\
\hline
\end{tabular}

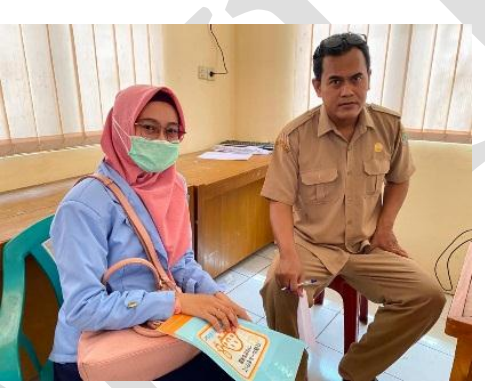

Gambar 1. Menemui sekdes cikampek timur
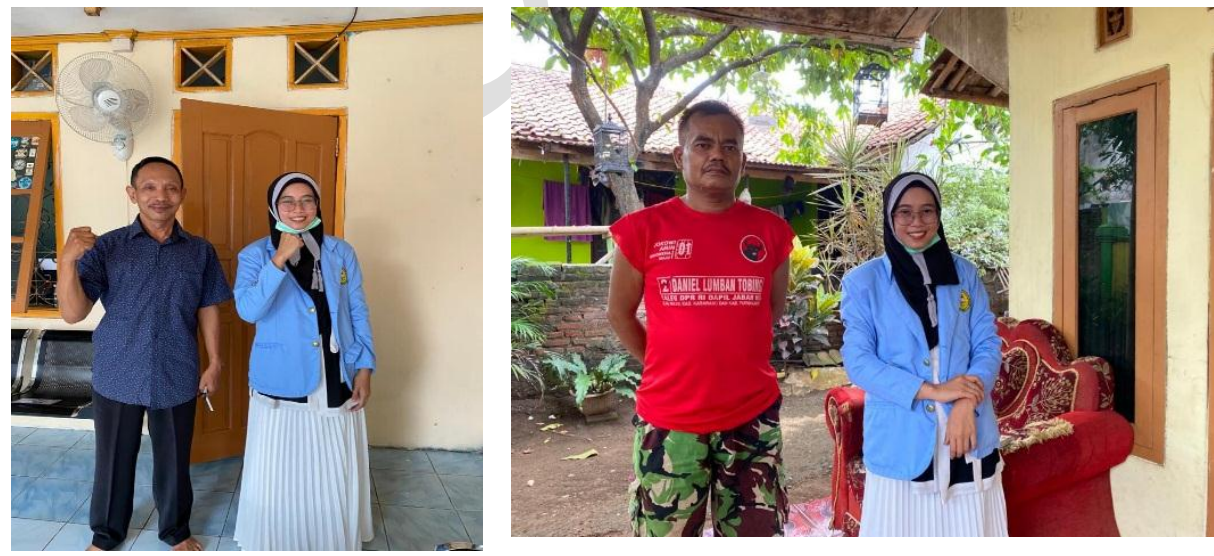

Gambar 2 dan 3. Menemui ketua RT dan tokoh setempat 
SIVITAS, Vol. 1. No. 2 Juli 2021, 71-80

Gambar 4 dan 5. Wawancara kepada para lansia

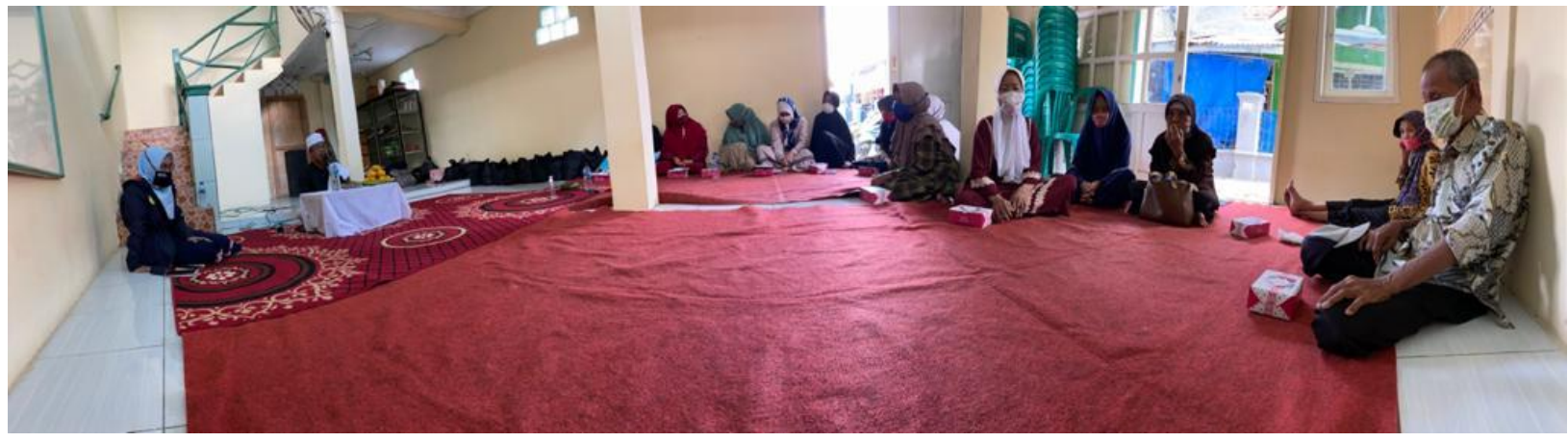

Gambar 6. Kegiatan Dzikir Bersama Lansia. MPP sebagai MC.
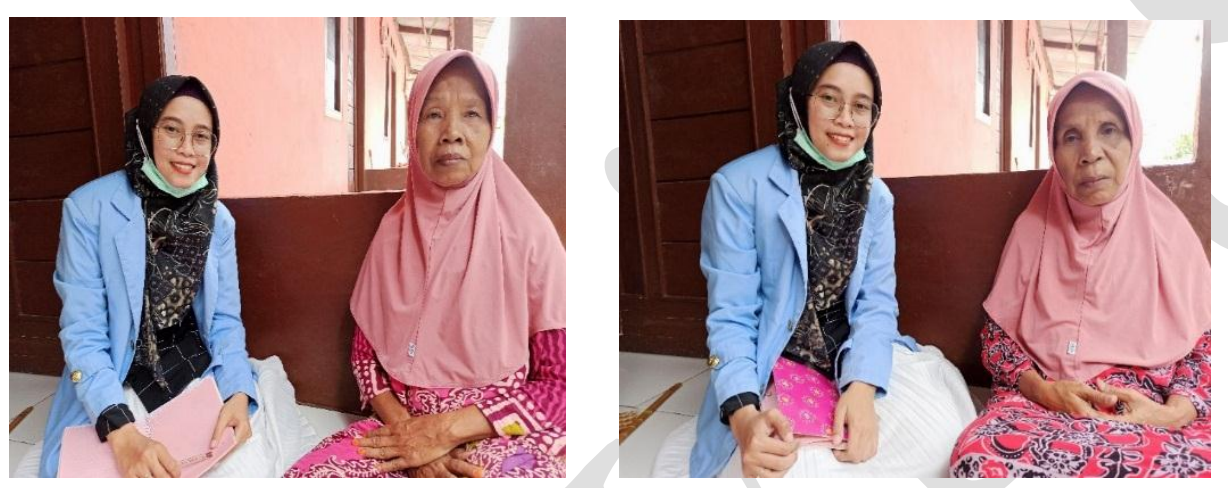

\section{KESIMPULAN}

Dari uraian kegiatan yang MPP lakukan, maka dapat disimpulkan bahwa: Pertama, pada kegiatan pra-tindakan, MPP mengunjungi beberapa informan, melakukan observasi kepada informan dan subyek penelitian (dalam hal ini adalah lansia); Kedua, Pada kegiatan pasca-tindakan, MPP menyelenggarakan kegiatan lansia mengaji dan bakti sosial.

\section{UCAPAN TERIMA KASIH}

Penulis mengucapkan terimakasih kepada donatur yang telah turut serta membantu finansial dalam kegiatan bakti sosial pada saat kajian Dzikir bersama lansia di Desa Cikampek Timur.

\section{DAFTAR PUSTAKA}

\section{Buku dan Jurnal:}

Darajat, D. (2010). Ilmu Jiwa Agama. Bulan Bintang. Idris, M. (2016). KONSEP ZIKIR DALAM AL-QUR'AN. Kartikadewi, A. (2015). Buku Ajar Psikiatri.

\section{Sumber Internet}

https://www.alodokter.com/gangguan-psikosomatis-ketika-pikiran-menyebabkan-penyakit$\underline{\text { fisik }}$

http://digilib.uinsby.ac.id/19636/4/Bab\%202.pdf. PSIKOLOGI AGAMA DAN PERANAN TERHADAP PEMBENTUKAN PERILAKU BERAGAMA. 